Tér és Társadalom 22. évf. 2008/4. 43-62. p.

Tér és Társadalom

XXII. évf. 2008 4: 43-62

\title{
BALATON RÉGIÓ
}

\author{
(Balaton Region)
}

\section{BUDAY-SÁNTHA ATTILA}

Kulcsszavak:

Balaton régió üdülöövezet idegenforgalom átfogófejlesztés

A tanulmány Szerzôje több évtizedes kutatásai alapján a Balatonnal kapcsolatos gondok természeti, társadalmi és gazdasági okaira keresi a választ. A minden részletre kiterjedỏ, a különbözö ágazatok hatását és azok kölcsönhatását egyaránt értékelö, komplex, térségi szemléletü vizsgálatok hozzásegitenek ahhoz, hogy a Balaton és üdülökörzete állapotának, fejlödésének alakulását jobban megismerjük, és lehetöségeink szerint azon változtatni tudjunk. A tanulmány nemcsak a szakemberek, de minden, a Balaton sorsáért aggódó ember számára is hasznos, információ gazdag olvasmányt jelenthet.

\section{A Régió lehatárolása}

A Balatonnak és környezetének lehatárolása napjainkig vita tárgyát képezi, mert az történhet természet- és gazdaságföldrajzi, fejlesztési és ágazati (funkcionális) szempontból is. Létezik egy vízrajzi lehatárolás, amely a vízgyüjtő területet veszi alapul. Ez az $5755 \mathrm{~km}^{2}$ terület mélyen belenyúlik Somogy és Zala megyékbe, és Veszprém megye jelentős részét is érinti. Ennek igazgatási és gazdasági szempontból az akadálya, hogy a vízgyüjtỏ terület tótól távol fekvő településeinek, népességének és gazdaságának a Balatonhoz való kapcsolódásának mértéke elhanyagolható.

A vízgyújtỏ területen belül a hetvenes években határolták el az üdülőövezetet (üdülőkörzetet), amely lényegében a Balaton régió területét jelenti (1. ábra). Ez a $3769 \mathrm{~km}^{2}$-nyi terület történelmileg három megyéhez, 1997-től három régióhoz tartozik, és tervezési régióstátussal rendelkezik. A régió 164 települése (16 város és 148 község) 14 kistérségbe van besorolva (1. táblázat). A 164 település közül 52 a part menti, 112 pedig az ún. háttértelepülések közé tartozik. A tervezési régió célját, indokát jelentő tó a térség tengelyében helyezkedik el, és mindenkori állapota és annak reális, illetve túlzó megítélése befolyásolja az egész térség életét és jövójét.

\section{TÁBLÁZAT}

A Balaton régió népességének alakulása

(Number of Population in the Selected Holiday Region of the Lake Balaton)

\begin{tabular}{lcccccc}
\hline \multirow{2}{*}{ Megnevezés } & \multicolumn{2}{c}{1990} & \multicolumn{2}{c}{2001} & \multicolumn{2}{c}{2005} \\
\cline { 2 - 7 } & ezer fö & $\%$ & ezer fö & $\%$ & ezer fö & $\%$ \\
\hline Városok & 137 & 54 & 135 & 53 & 135 & 53 \\
Falvak & 118 & 46 & 120 & 47 & 118 & 47 \\
Régió összesen & 255 & 100 & 255 & 100 & 253 & 100 \\
\hline
\end{tabular}

Forrás: Hablicsek (2003, 10); A Balaton Üdülökörzet... (2006, 55). 


\section{1. ÁBRA}

A Balaton és kiemelt üdülökörzete

(The Lake Balaton and its Selected Holiday Region)

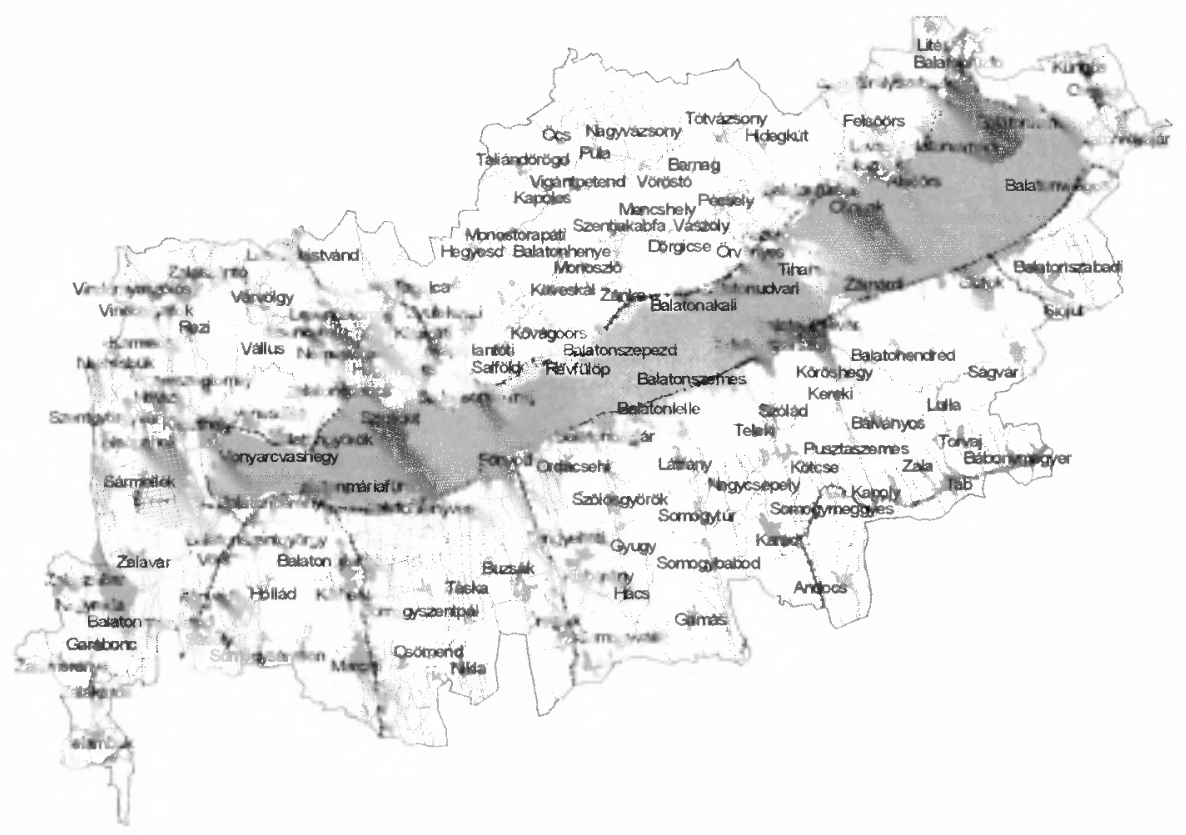

Forrás: A Balaton Régió... (2005, 18).

\section{A Balaton helyzetének megitélése}

A Balatonról ma kettős kép él a köztudatban. Az egyiket az irodalmi munkák, idegenforgalmi reklámanyagok tükrözik, amelyek - sok esetben nem nélkülözik az olyan túlzásokat, hogy páratlan, egyedülálló, magyar tenger - a tó selymes vizét, a gyerekek számára ideális homokos fürdőhelyeket, a vízi sportok lehetőségének a gazdagságát, a táj szépségét, változatosságát, a felkínált ételek és borok finomságát, a térség gazdag kulturális örökségét emelik ki. És ez igaz is, mert a Balaton nem egy tó a tavak sorában, hiszen könnyen felmelegedő, sekély vize fürdésre kiválóan alkalmassá teszi, élővilága rendkívül gazdag, a táj változatos vulkanikus kúpjaival sok tekintetben egyedi. A környezetében kiváló élelmiszerek és borok termelhetök, amelyek a változatos gasztronómiai kínálat alapját jelenthetik. A térség kulturális öröksége is gazdag, bár elsősorban a nemzeti vonatkozásai jelentősek.

A balatoni táj nem meghökkentő természeti adottságai, egyedi építészeti értékei, hanem elsősorban szelídsége, harmóniája, emberléptékủsége miatt megragadó. A maga kis városaival, falvaival, a hegyre felkapaszkodó szőlőivel, gyümölcsöseivel, kápolnáival, templomaival tipikus közép-európai táj, amely egy történelmi örökséget (templomok, várromok, kastélyok) hordó agrár tájból az elmúlt másfél 
évszázad alatt alakult át idegenforgalmi tájjá, ahol az épített környezetét már a turisztikai célok alakították és alakítják. Ez az a Balaton kép, ami miatt érdemes még nagy távolságról is idejönni és azt a kikapcsolódás, üdülés helyéül választani.

A térség egyedi jellegét adó előnyök azonban könnyen hátránnyá válnak. A sekély, könnyen felmelegedó víz egyben a tó nagyfokú érzékenységét is jelzi mindenféle szennyezéssel szemben. A környezet kultúrtáj jellege, agrár és idegenforgalmi jellegủ hasznosítása nagy terhelést (kemikáliákkal szennyezett eróziós hordalék, települések szennye, szennyvize) jelenthet erre az érzékeny tóra. Ma már történelmi visszatekintéssel tudjuk értékelni azt a folyamatot, mely során - föleg a hatvanas évek elejétöl kezdve - egyre nagyobb mértékben elszennyeződött, majd pedig a különféle intézkedésekre bekövetkezett terhelés csökkenésének hatására ismét tisztulni kezdett a tó vize. Kezdetben a tó sorsáért való aggódás indította el, majd pedig a szenzációkeltés erősítette fel azt a folyamatot, melynek hatására a Balaton mindenféle bajt hordozó állatorvosi lóként jelenik meg a köztudatban. A Balaton egyenlővé vált a feliszaposodással, az algásodással, a nád- és halpusztulással, az alacsony és nagy vízállással, a kultúrálatlan környezettel, a vendégek megvágásával, a bünözés megjelenésével. Mindebben volt igazság, de a túl egyoldalúra sikerült kép erősen beivódott nemcsak a hazaiak, de a külföldiek tudatába is, és ez a térséget minden tekintetben erősen leértékelte. Az így kialakult negatív kép pontosan annak a harmóniának, nyugalomnak, biztonságnak mond ellent, amely ennek a térségnek az értékét jelenti, illetve jelentheti.

\section{A bajok eredete}

A bajok alapvető okát a fejlödés megkésettségében, komplexitásának hiányában, szabályozatlanságában, sok esetben spontán jellegében kereshetjük. A Balaton sorsát hosszú időn keresztül az agrár érdekek (földnyerés) befolyásolták, melynek hatására a nagy kiterjedésủ mocsarak lecsapolásával (Nagyberek, Tapolcai-medence, Kis-Balaton, Zala-völgye), 1863 óta vízszintjének szabályozásával területének közel $40 \%$-át, víztömegének pedig kb. $50 \%$-át elvesztette. A Balaton térsége egy kimondottan agrártájból - ahol a tó haszna (nád, hal) nem volt arányban azzal a kárral, amilyen közlekedési akadályt a tó jelentett - a 19. század végétöl kezdve kezdett átalakulni üdülőtájjá. Ebben a lassú átalakulással járó folyamatban a robbanásszerú változás a hatvanas években, a tömegturizmus megjelenésével következett be, mely során az üdülővendégek száma néhány év alatt pár tízezerről több százezerre nött, és vele együtt a növekvő munkahely kínálat miatt megnött a térség állandó lakossága is. A növekvő kereslettel a fejlesztési lehetőségek nem tudtak lépést tartani, és különösen a hatvanas években bekövetkezett vendégszám növekedés következtében a szolgáltatások terén olyan súlyos hiányok jelentkeztek, amelyek közegészségügyi veszélyekkel is jártak. A térség infrastrukturális elmaradottságát jól mutatja az, hogy a történelmileg legnagyobb településén, Keszthely belvárosában is csak 1941-ben épült ki a vízvezeték, és 1957-ben is csak három településen (Keszt- 
hely, Siófok, Balatonfüred) volt, összesen csak $16 \mathrm{~km}$ hosszú szennyvízvezeték, amellyel a szennyvizet a nádasokba vezették. A fejlesztés így az igények után futott. Elsődleges feladatot az egészséges vezetékes vízellátás kiépítése és a kereskedelmi szolgáltatások fejlesztése jelentette. A part menti települések vízellátását is csak a nyolcvanas évek elejére tudták megoldani, míg ezeknek a településeknek a csatornázottsága és szennyvíz kezelése csak 2007-re készült el teljes egészében, de a tóra hatást gyakorló ún. háttértelepüléseken még napjainkig sem épült ki mindenütt. Meleg nyári napokon a nyolcvanas években az üdülökkel egy millió före felszaporodó népességú, part menti települések szennyvize, - amely közvetlenül, illetve szikkasztókból a talajvízzel került a tóba - jelentette a legnagyobb veszélyt a tóra. A helyzetet tovább rontotta, hogy az ipartelepítéssel egyidejüleg gyorsan növekvö népességủ városokból a patakok (Marcali, Tapolca) és a Zala (Zalaegerszeg, Zalaszentgrót) már erősen szennyezett vizet szállítottak a tóba. A fejlesztéseknél nemcsak a komplex szemlélet (vízellátás - csatornázás, szennyvíztisztítás), de a térségi szemlélet sem érvényesült, ezért épülhetett Keszthelyen Tejüzem és Vágóhíd tisztító nélkül, és ezért létesülhettek hígtrágyás állattartó telepek a tó közvetlen közelében. Sajnos a térség fejlesztése során nem törekedtek az ágazati fejlesztések összehangolására és a tó védelmét figyelmen kívuil hagyták, ez súlyos gazdasági (pl. állattartó telepeket fel kellett számolni) és környezeti következményekkel járt. A következetes szabályozás hiánya, fỏleg az üdülők létesítése területén hozzájárult, hogy korábbi mezőgazdasági, föleg szőlőterületeken megfelelő infrastruktúra nélkül üdülötelepek alakuljanak ki, illetve a parti területeken a magántulajdonosok legálisan, illetve illegálisan (pl. nádasok feltöltése) olyan területek birtokába jussanak, és azokon olyan tevékenységeket végezzenek, amelyek a közösségi célú fejlesztések számára akadályt képeznek és a víz minőségére káros hatást gyakorolnak.

\section{Térség gazdasága}

A térség rendkívül változatos domborzati jellege, talajainak eltérỏ minősége alapján mozaikszerủen változó, de összességében csak közepes minőségü mezőgazdasági területnek tekinthető. A kimondottan kiváló (pl. Balatonkenese, Siófok térsége) és kedvezötlen (pl. Nagyberek) termöhelyek mellett szinte minden növény számára található olyan terület, ahol versenyképes termelésre lehetőség nyílik. A térség egészében a természeti feltételek föleg a szőlö- és gyümölcstermesztés számára kedvezőbbek az átlagosnál. A szölö- és bortermelés a Balaton-felvidék meredek fekvésú, sekély termőrétegü, sülevényes talaján nem csak lehetőség, hanem kényszer is, mert versenyképes termelésre csak ezzel az ágazattal nyílik lehetőség akkor, ha nem a mennyiség, hanem kimondottan a minöség áll a termelés központjában.

Mivel a térség az építóanyagokat (kő, murva, homok) leszámítva nem rendelkezik számottevő nyersanyag forrással és olyan nagyváros sincs a térségben, amely az ipar számára vonzerőt jelentene, ezért a part menti települések ipari fejlődése nem volt jelentős. Számottevő ipar csak Keszthelyen (élelmiszeripar és textilipar), Bala- 
tonfüreden (hajóépítés) és Balatonfüzfön (vegyipar, papíripar) alakult ki. Az ipari fejlödés - szerencsére - a vízgyüjtó parttól távolabb fekvő városokra (Marcali, Tapolca, Zalaszentgrót, Zalaegerszeg, Nagykanizsa) koncentrálódott, és a rendszerváltás óta a part menti ipar többsége is leépült (pl. Keszthelyen a tejüzem és vágóhíd bezárt, Balatonfüreden a hajógyártás megszünt).

Így már a 19. század vége óta világossá vált, hogy a térség fejlesztése a Balatonra épülö idegenforgalomra alapozódhat, csak az idegenforgalom és az arra épülö szolgáltatások fejlődése emelheti ki a közepes adottságokkal rendelkező agrártérséget alulfejlett állapotából. Az elmúlt száz év azonban azt is bizonyította, hogy mivel az idegenforgalom $90 \%$-ban a part menti településekre és ott is föleg a városokra koncentrálódik, a térség és a népessége túl nagy és az idegenforgalom túl idényszerủ ahhoz, hogy egyetlen gazdasági ágazat a terület hasznosítását, a népesség foglalkoztatását meg tudná oldani. Az agrárgazdaság (mező- és erdőgazdaság), valamint az idegenforgalom együttélése látszólag rendkívül kedvezö, hiszen az idegenforgalom helyi piacot biztosít az agártermékek számára, a színvonalas agrártermelés viszont az ápolt kultúrtájjal megfelelö hátteret, kiegészítő szolgáltatásokat (éttermek, szállodák részére friss zöldséget, gyümölcsöt, bortúrát) nyújt az igényes idegenforgalom részére. Sajnos ez a természetes együttélés a szőlő- és bortermelést leszámítva a kívánatos módon sohasem valósult meg, és csak a szölö- és borágazat volt az, amely a múltban és napjaikban is szervesen kapcsolódni tudott az idegenforgalomhoz. A mezőgazdasági termelés nem tudott az időjárástól erősen függő szezonális kereslethez igazodni, és a térségben nem épült ki az a logisztikai bázis (hütőházak, raktárak, nagybani piac), amely az erősen változó keresletet kiegyenlíteni és kielégíteni tudta volna. Ebben nem kevés szerepe volt a szolgáltatások, mindenekelött a vendéglátás igénytelenségének, amely a minőségi áruellátás javítása érdekében (pl. friss élelmiszerek) sohasem törekedett tartós termelői kapcsolatok kialakítására. Ennek az eredménye volt az, hogy a Balaton mellett megtermelt zöldséget és gyümölcsöt többnyire a budapesti nagybani piacon értékesítették, illetve exportálták, vagy konzerv- és édesipari üzemeknek adták át, míg a térség ellátásához szükséges árut Budapeströl és az Alföldröl szállították a Balaton mellé. Ebből adódóan a térség agrárgazdasága az idegenforgalom fejlödésének nem az előnyeit, hanem inkább a hátrányait érezte, amely a szezonális munkaerö nagyobb drágaságában és a termelést terhelő fokozott környezetvédelmi követelményekböl adódó nagyobb termelési költségekben mutatkozott meg. Kedvezötlen jelenség, hogy a rendszerváltás óta a nagyüzemek felszámolása, a földek privatizálása, a földspekuláció megjelenése következtében a területek müvelési színvonala romlott, nagyszámú ültetvény (gyümölcsösök, szőlők) a szakszerütlen használat miatt tönkre ment. A létrejött kisgazdaságok többsége nem képes fejlesztésre, korszerủ termelésre, és ez a táj állapotán is meglátszik. 


\section{A régió helyzete ma}

A három évtizedes gyors fejlödés után - amely azonban elsősorban a városokat és a part menti településeket érintette - a rendszerváltást követỏen a régió válságba került. A válság a természeti környezet állapotában, a térség gazdasági teljesitményének, a népesség foglalkoztatási helyzetének, jövedelmének alakulásában egyaránt megmutatkozott. A víz minősége a nyolcvanas évek intézkedéseinek hatására (Kis-Balaton I. üteme, csatornázás, szennyvíztisztítás fejlesztése, patakmedrek erdősítése, a patakok vizének víztározókba való ülepítése, torkolati részükön szürömezők létesítése, hígtrágyás állattartó telepek felszámolása, a talajba injektált folyékony mütrágyák elterjesztése stb.) bekövetkezett általános javulása után ismét romlani kezdett, és 1994-re történelme során a legrosszabb vízminőséget érte el (2., 3. ábra). Az egész tó a felszaporodó algák miatt hipertróffá vált, amit az évente rendszeressé váló halpusztulások (keszeg, busa, angolna) is jeleztek. Mindez arra utalt, hogy az előzỏ évtized fejlesztései csak a romlási folyamat lelassítására voltak elegendőek, de kedvező hatásuk rövid idö alatt kimerült.

\section{2. ÁBRA}

Klorofill-a éves átlagok

(Clorophill A-Annual Averages)

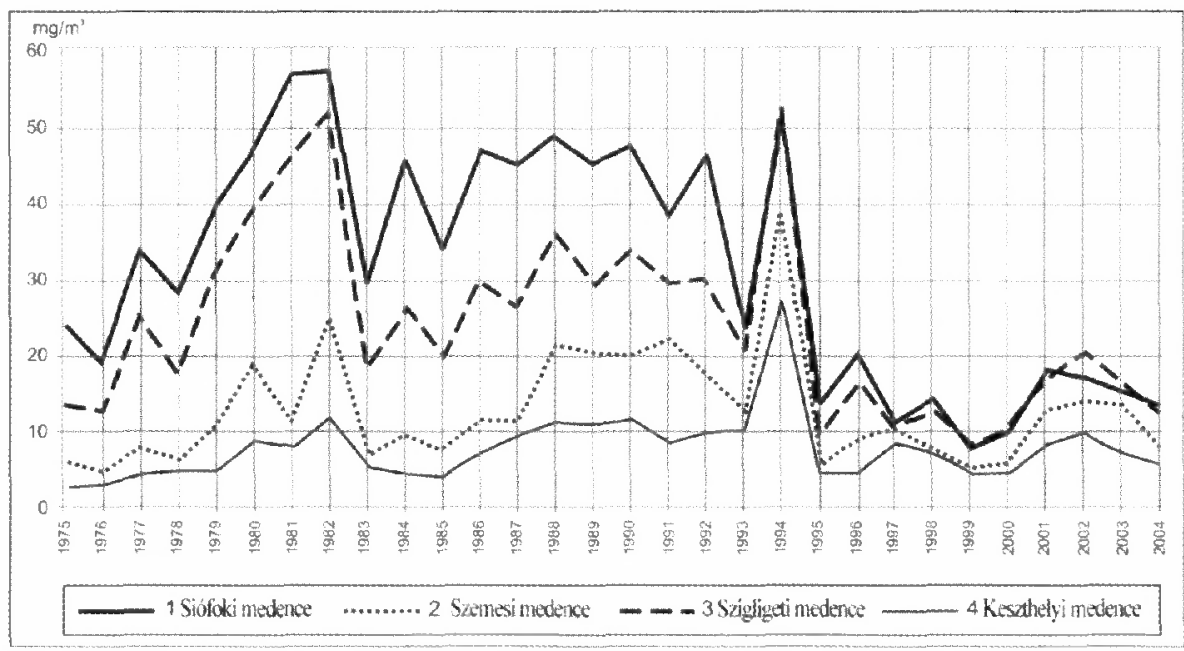

Forrás: Katona-Örsi (2006, 4. ábra).

A kialakult helyzetet drámaian tárgyaló hazai és külföldi sajtó hatására a balatoni üdülés vonzása csökkent. A térség gazdasági alapját jelentő turizmus természeti bázisának romlása csak elmélyítette a rendszerváltással szükségszerủen jelentkező gondokat. Nagyon lényeges, hogy a határnyitással, illetve a német újraegyesítéssel a Balaton megszünt a német turisták legális találkozóhelyének lenni, ami a külföldi turisták $60 \%$-át adó német turisták számának kezdetben rohamos, majd lassuló, de napjainkig tartó csökkenésével járt együtt. 


\section{3. ÁBRA}

A Balaton vizminöségének alakulása

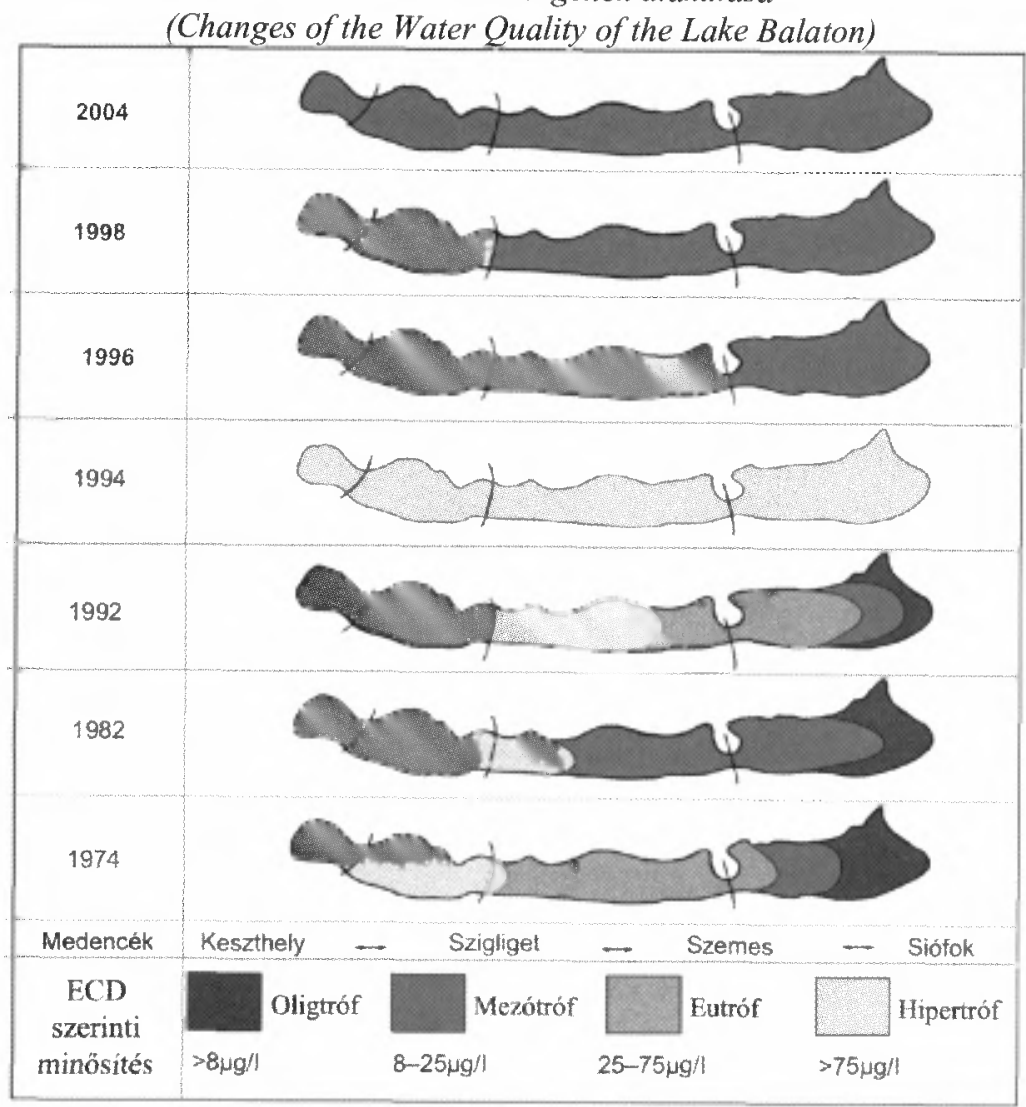

Forrás: Katona-Örsi $(2006,26)$.

A határok megnyitásával nemcsak a hazai, de a korábbi szocialista országok turistáinak célterületeivé az addig nehezen elérhetô tengerpartok, európai és tengerentúli országok, fürdóhelyek váltak. Ezáltal a balatoni turista-fogadás feltételei nemzetközi összehasonlításban kerültek mérlegre, és gyakran könnyủnek találtattak, mert kiderült, hogy a hazai szolgáltatások színvonala többnyire nem éri el a nemzetközi szintet és azt is viszonylag drágán, eléggé megbízhatatlan módon nyúitja. A lakossági jövedelmek csökkenése, a munkahelyek megszünése és a váratlanul tömegessé váló munkanélküliség az üdülési szokások megváltoztatására kényszerítette az alacsonyabb jövedelmủ lakosság széles rétegeit. Ezt gyorsította fel a szakszervezeti és ifjúsági üdültetés lényegében véve teljes megszünése, melynek következtében több millióval csökkent az üdülök száma. A túlnyomórészt kereskedelmi szálláshelyekre alapozott üdülỏ népesség pedig rendkívül érzékenyen reagál az időjárás alakulására, és emiatt az üdülési szezonon belül is kiszámíthatatlanul változott a szolgáltatásokat igénybe vevök száma (2., 3. táblázat). A balatoni turizmus image-nek nem tett jót a szakképzetlen vállalkozók (vendéglősök, panziótulajdonosok) tömeges megjelenése, 
akik a váratlanul lecsökkent és az időjárás miatt bizonytalanná vált keresletet magasabb árakkal próbálták ellensúlyozni. Különösen a külföldiek számára volt ijesztö a közrend romlása miatt a hazai és külföldi bünözók tömeges megjelenése, amit a lopások, betörések, autólopások növekvố száma jelzett.

\section{TÁBLÁZAT}

Kereskedelmi szálláshelyek forgalma a Balaton régióban* (ezer fó) (Turnover of Commercial Accommodations in the Balaton Region [in Thousand])

\begin{tabular}{|c|c|c|c|c|c|}
\hline Megnevezés & 1980 & 1986 & 1990 & 2000 & 2005 \\
\hline Vendégek száma & 825 & 1008 & 725 & 823 & 976 \\
\hline ebbỏl: $\quad$ külföldi & 473 & 686 & 561 & 419 & 386 \\
\hline $\begin{array}{l}\text { Vendégéjszakák } \\
\text { száma }\end{array}$ & 6188 & 7897 & 5341 & 3735 & 3941 \\
\hline ebből: külföldi & 3358 & 5492 & 4280 & 2457 & 2189 \\
\hline
\end{tabular}

*Fizetôvendéglátás nélkül

Forrás: Statisztikai Évkönyv (1980, 350); Idegenforgalmi Évkönyv (1986, 240-256); Statisztikai Zsebkönyvek (1999, 258; 2005, 291).

\section{TÁBLÁZAT}

A kereskedelmi szálláshelyeket igénybe vevỏ külföldi turisták aránya (Average of Foreign Tourists Using Commercial Accommodations)

\begin{tabular}{lccccc}
\hline \multicolumn{1}{c}{ Megnevezés } & 1980 & 1986 & 1990 & 2000 & 2005 \\
\hline Külföldi turisták aránya (\%) & 57 & 68 & 77 & 51 & 40 \\
Külföldi vendégéjszakák aránya (\%) & 54 & 70 & 80 & 66 & 56 \\
\hline
\end{tabular}

Forrás: KSH adatok alapján saját számítás.

A turizmus visszaesése azért is volt aggasztó, mert a rendszerváltást követően az üzembezárások hatására az ipari foglalkoztatás is csökkent, a mezőgazdaságban pedig a nagyüzemek felszámolásával jelentós számú, főleg szakképzetlen munkaerỏ szabadult fel.

A gazdaságilag kedvezőtlen folyamat az ezredfordulóra javulni kezdett. Ebben döntő jelentősége volt annak, hogy a jelentôs infrastrukturális fejlesztések (fóleg a csatornázás és szennyvíztisztítás), továbbá a Kis-Balaton II. ütemének részleges üzembe helyezésének hatására a víz minősége gyorsan javult, és a régen megcélzott, a hatvanas évek vízminőségi állapotát megközelítő vízminőség alakult ki. Ezzel egyidejüleg jelentős szállodai és fürdő fejlesztéseket hajtottak végre, és folyamatosan javultak a gyógyvizekre épülő turizmus feltételei is (pl. Hévíz, Zalakaros, Kehidakustány, Tapolca). Erre szükség is volt, mert az idelátogatók már az igényesebb szálláshelyeket (három és négy csillagos szállodákat) keresik, míg a magán szálláshelyek, panziók, kempingek, egy, illetve két csillagos szálláshelyek iránti kereslet jelentősen lecsökkent (4. ábra). Az is világossá vált, hogy a balatoni turizmus idényszerüségét és idényen belül az időjárásnak való kitettségét csak a melegvizes fürdőhelyek számának növelésével és a szolgáltatások színvonalának, minöségének a javításával lehet elérni. 


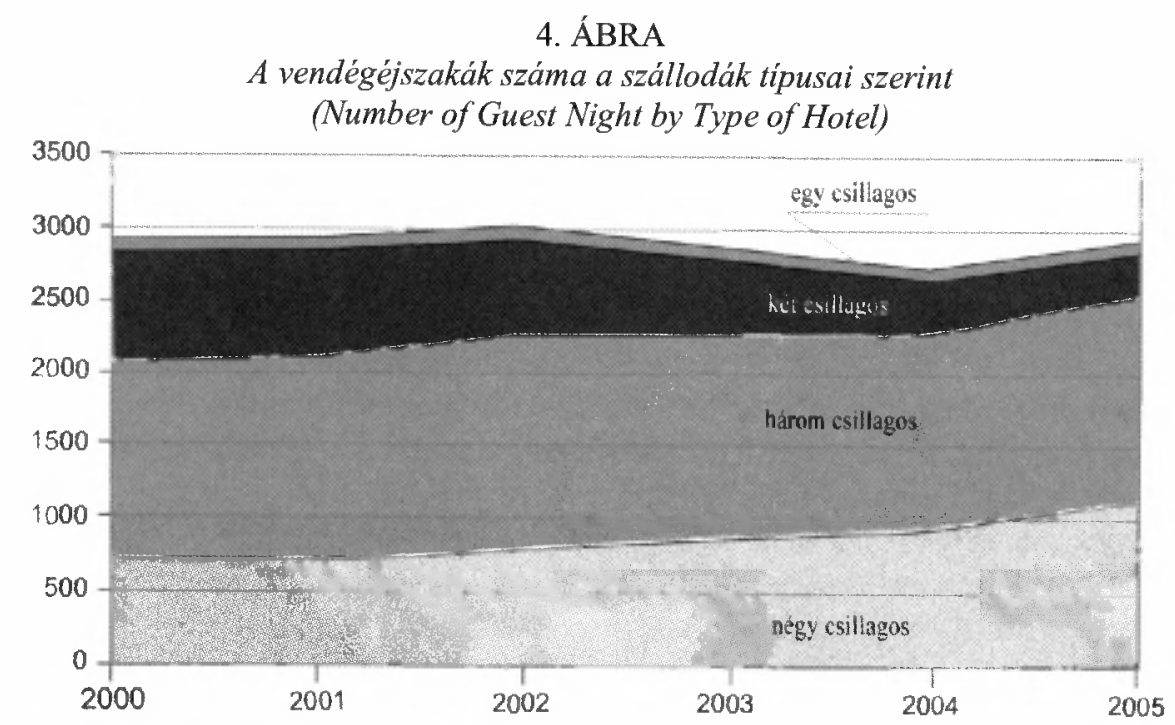

Forrás: A Balaton üdülőkörzet... $(2006,25)$.

$\mathrm{Az}$ üdülési feltételek lényeges javulása sem állította meg a külföldi látogatók számának csökkenését, de a belföldi turisták száma ismét növekedésnek indult. Ez mindenekelött az üdülési csekk bevezetésének volt köszönhetö, de szerepet játszott benne az életszínvonal ismételt lassú emelkedése, valamint az is, hogy a külföldi utazások magasabb költségei és fáradalmai után az érdeklödés ismét a könnyen megközelíthetö Balaton felé fordult. A belföldi vendégek számának növekedése azonban eddig csak részben tudta pótolni a külföldiek számának csökkenését, mert a magyar vendégek rövidebb ideig veszik igénybe a szálláshelyeket. A magyar turisztikai kínálat a rendszerváltással a turizmus nemzetközi kínálati piacára került és csak akkor tud versenyben maradni, ha elérhetőségében, természeti feltételeiben, szolgáltatásainak színvonalában felveszi a versenyt más üdülőhelyekkel. A rendszerváltással a turizmus - minden nehézsége ellenére - a térség számára felértékelödött, mert a turizmus és az ahhoz kapcsolódó szolgáltatások képesek a térség gazdasági teljesítményének a növelésére, a foglalkoztatási helyzet javítására. Számottevő ipar vonzására a régió a jövőben sem lesz képes, az agrártermelés pedig a nagyüzemek felszámolása óta válságban van. A térségben egyetlen pozitív jelként a korábbi nagyüzemi ültetvények bázisán kialakult, kimondottan minöségorientált 10-100 hektáros szóló- és borgazdaságokat tekinthetjük, amelyek borai jól tükrözik a térség kiemelkedően jó termőhelyi potenciálját. Sajnos ezek a gazdaságok a térség szőlötermelésének legfeljebb 20\%-ával rendelkeznek, és ez nem elegendö ahhoz, hogy a régióban a versenyképes szőlö- és bortermelés feltételei létrejöjjenek. A sikerhez a termelök nagyobb mértékú együttmủködésére, kevesebb számú, nagyobb területü gazdaságokra és egy egységes bormarketingre lenne szükség, mert elképzelhetetlen, hogy a térségben jelenlévő kis termőterületü borrégió termelői egymással versenyezve a nemzetközi piacokra ki tudjanak lépni és ott sikeresen helyt is tudjanak állni. 


\section{A fejlesztés indokai, gondjai}

Egy térség fejlesztése akkor lehet sikeres, ha a fejlesztés komplex módon, a gazdasági, szociális és ökológiai szempontok figyelembevételével, az ágazatok közötti együttmúködés által kiváltott szinergikus hatások kihasználásával megy végbe. A jelenleg jelentkező gondok a következőkben foglalhatók össze:

- A Balaton vize jó minöségü, de állapota labilis, folyamatosan jelentős szenynyezésnek van kitéve (4. táblázat). Ennek ellenére nem látszanak - az elég vontatottan végbemenö csatornázástól eltekintve - azok a programok, amelyek a jelenlegi jó vízminőségi állapot fenntartását, folyamatos javítását (nem kampányszerủ beavatkozásokkal) biztosítanák. (Pl. meder kotrása, az erózió veszélyes területek erdősítése, a Balatonba futó vizek elöülepítése stb.)

\section{TÁBLÁZAT}

\section{A Balatont érö összes terhelés}

(Changes of the Water Quality of the Lake Balaton)

\begin{tabular}{|c|c|c|c|c|c|c|}
\hline \multicolumn{7}{|c|}{ A Balaton nitrogén terhelése $(t)$} \\
\hline$\dot{E} v$ & Vizfolyások & $\begin{array}{l}\text { Közvetlen } \\
\text { szennyviz }\end{array}$ & $\begin{array}{l}\text { Bemosódás } \\
\text { városi } \\
\text { területekröl }\end{array}$ & $\begin{array}{c}\text { Egyéb } \\
\text { közvetlen } \\
\text { bemosódás }\end{array}$ & $\begin{array}{l}\text { Légköri } \\
\text { terhelés }\end{array}$ & $\begin{array}{c}\text { Becsült } \\
\text { összes } \\
\text { terhelés }\end{array}$ \\
\hline $1975-79$ & 1599 & 229 & 118 & 200 & 590 & 2736 \\
\hline 1985 & 2331 & 72 & 115 & 230 & 561 & 3309 \\
\hline 1990 & 964 & 23 & 104 & 128 & 591 & 1810 \\
\hline 1995 & 1266 & 35 & 207 & 236 & 1836 & 3580 \\
\hline 2000 & 699 & 4 & 135 & 200 & 1448 & 2485 \\
\hline 2004 & 1032 & 4 & 125 & 157 & 1448 & 2766 \\
\hline $2004 \%$ & 37,3 & 0,1 & 4,5 & 5,7 & 52,4 & 100,0 \\
\hline \multicolumn{7}{|c|}{ Balaton foszfor terhelése ( $t$ ) } \\
\hline $1975-79$ & 157 & 32 & 58 & 18 & 62 & 327 \\
\hline 1985 & 171 & 7 & 57 & 70 & 19 & 324 \\
\hline 1990 & 72 & 2 & 47 & 38 & 34 & 193 \\
\hline 1995 & 77,1 & 0,8 & 41,4 & 70,7 & 10 & 200 \\
\hline 2000 & 36 & 0,3 & 33 & 73 & 12,4 & 155 \\
\hline 2004 & 36,6 & 0,5 & 31 & 58,2 & 12,4 & 139 \\
\hline $2004 \%$ & 26,4 & 0,4 & 22,4 & 41,9 & 8,9 & 100,0 \\
\hline
\end{tabular}

Forrás: Katona-Örsi (2006, 23. melléklet) alapján.

- A fejlesztéseknél rendkívül alacsony a különböző ágazatok, hatóságok, önkormányzatok és a vállalkozók között az együttmüködési hajlandóság, a közös fejlesztésekre való törekvés. Itt mindenekelött az idegenforgalom és a mezögazdaság nagyobb fokú integrációjának, a természetvédelem, a vízgazdálkodás és a gazdaság közötti nagyobb együttmüködési készségnek a hiányát lehet kiemelni. De összefogás, közös fellépés helyett versenyeznek egymással a települések, a turisztikai szervezetek és a bortermelők is.

Az előzőekből adódóan a fejlesztések erösen szétforgácsoltak, a részérdekektöl erösen motiváltak és alacsony hatékonyságúak. 
A térség gazdasági fejlődése lelassult, gazdasági pozíciója az ország más térségeihez képest fokozatosan romlik. Ezért míg a Balaton régiót és Budapestet is magában foglaló 21 megye rangsorában az 1 före jutó GDP alapján a régió 1994-ben még Budapest után a 2. helyet foglalta el, addig alacsonyabb gazdasági fejlődése miatt 2004-re az 5. helyre csúszott vissza (5. ábra) 1994 és 2004 között a régió súlya az ország GDP termelésében 2,9\%-ról 2,5\%-ra csökkent (Löcsei-Németh 2006). Ebben az időszakban a Balaton régiót magában foglaló három megye GDP termelésében a régió súlya 35,2\%-ról 31,9\%-ra mérséklődött. Míg 1994-ben az 1 före jutó GDP 17\%-kal meghaladta az országos átlagot, addig 2004-ben annak csak $99 \%$-át érte el, ami ugyan 26\%-kal még mindig magasabb a vidéki átlagnál, de ez az érték 1994-ben még $45 \%$ volt. A pozíció vesztés a régión belül a part menti települések esetén is érezhetö, mert míg 1994-ben az 1 före jutó GDP 62\%-kal haladta meg az országos átlagot, addig 2004-ben már csak 27\%-kal (Löcsei-Németh 2006) (5. táblázat).

\section{5. ÁBRA}

A megyék és a Balaton régió egy före jutó GDP értéke (országos átlag=100\%), 2000 (GDP per Capita in the Hungarian Counties and the Balaton Region

[National Average $=100 \%], 2000$ )

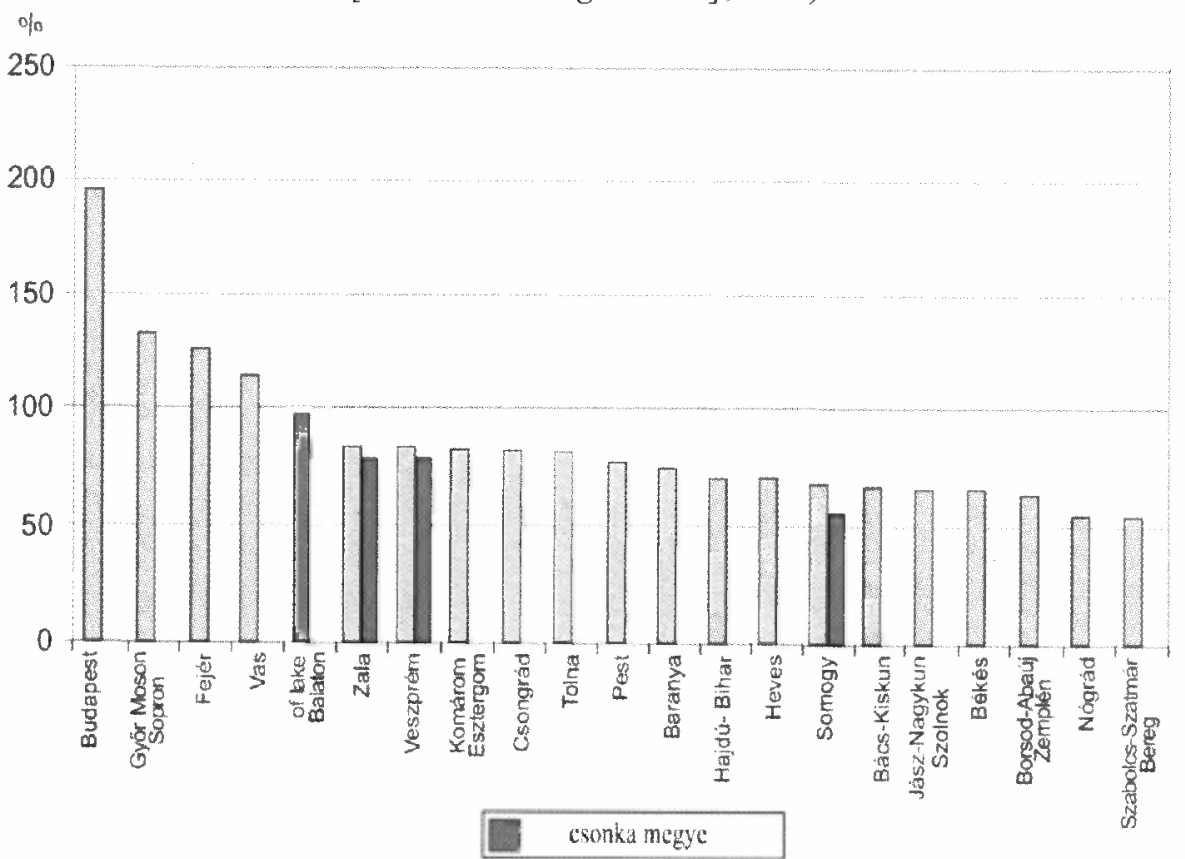

Forrás: Oláh $(2007,6)$. 


\section{TÁBLÁZAT}

A térség gazdasági erejének becsült nagysága a Balaton régió területén (GDP, Mrd Ft)

(Estimated Volume of the Economic Capacity of the Area in the Balaton Region)

\begin{tabular}{|c|c|c|c|c|c|c|c|}
\hline \multirow{2}{*}{ Megnevezés } & 1994 & 2000 & 2004 & $\begin{array}{c}2004 \\
1994 \\
\%-a ́ b a n\end{array}$ & 1994 & 2000 & 2004 \\
\hline & \multicolumn{4}{|c|}{$\begin{array}{l}\text { Becsült GDP termelés } \\
\text { (Mrd Ft) }\end{array}$} & \multicolumn{3}{|c|}{$\begin{array}{c}\text { Egy lakosra jutó GDP } \\
\text { az országos átlag } \\
\% \text {-ában }\end{array}$} \\
\hline $\begin{array}{l}\text { A régióban érintett } \\
\text { megyék együtt az ország } \\
\% \text {-ában }\end{array}$ & 8,2 & 7,9 & 7,8 & - & 83,2 & 79,7 & 78,9 \\
\hline $\mathrm{A} B \mathrm{BR}$ tényleges területe & 126,4 & 343,0 & 507,2 & 401 & 117,4 & 104,0 & 99,0 \\
\hline Ebből: Somogy & 52,6 & 141,0 & 213,1 & 405 & 108,3 & 95,2 & 92,8 \\
\hline Veszprém & 42,8 & 127,0 & 174,0 & 407 & 111,7 & 108,0 & 95,7 \\
\hline Zala & 30,9 & 74,9 & 120,0 & 388 & 149,4 & 118,0 & 118,6 \\
\hline Parti sáv & 99,3 & 258,0 & 377,5 & 380 & 162,0 & 138,0 & 127,0 \\
\hline Háttértelepülések & 27,1 & 84,5 & 129,7 & 479 & 58,4 & 59,5 & 60,3 \\
\hline Városok & 82,4 & 216,0 & 313,7 & 381 & 141,9 & 122,0 & 114,1 \\
\hline Községek & 44,0 & 127,0 & 193,5 & 440 & 88,7 & 83,3 & 81,4 \\
\hline $\begin{array}{l}\text { BR tényleges területe } \\
\text { az ország \%-ában }\end{array}$ & 2,9 & 2,6 & 2,5 & - & - & - & - \\
\hline $\begin{array}{l}\text { BR tényleges területe } \\
\text { a Budapest nélküli ország } \\
\text { \%-ában }\end{array}$ & 4,4 & 4,0 & 3,8 & - & - & - & - \\
\hline $\begin{array}{l}\text { BR tényleges területe a } \\
\text { három megye \%-ában }\end{array}$ & 35,2 & 32,9 & 31,9 & - & - & - & - \\
\hline
\end{tabular}

Forrás: Lỏcsei-Németh $(2006,11 ; 15) 1$. és 3 . táblázatának adatai alapján.

- A térség gazdasági fejlettségét, szociális és kulturális ellátottsági színvonalát tekintve rendkívül heterogén (6. ábra). Az idegenforgalom zömmel a part menti településekre és azon belül a városokba irányul, a régió 164 települése közül 31 abba egyảltalán nem tudott bekapcsolódni. Így jelentős gazdasági fejlettségi különbség alakul ki a városok és falvak, valamint a part menti települések és a háttértelepülések között. A gazdasági fejlettség terén jelentkező különbség a szociális jellegư ellátás színvonalára is rányomja a bélyegét. Ebből adódóan a háttértelepüléseken élőknek kevesebb a jövedelme, magasabb a munkanélküliség aránya, alacsonyabb a képzettsége és a rosszabb egészségügyi ellátás miatt rövidebb az élettartama. 


\section{6. ÁBRA}

Az egy társas vállalkozásra jutó saját töke összege (eFt) (Amount of Capital Assets per Company [Thousand Ft])

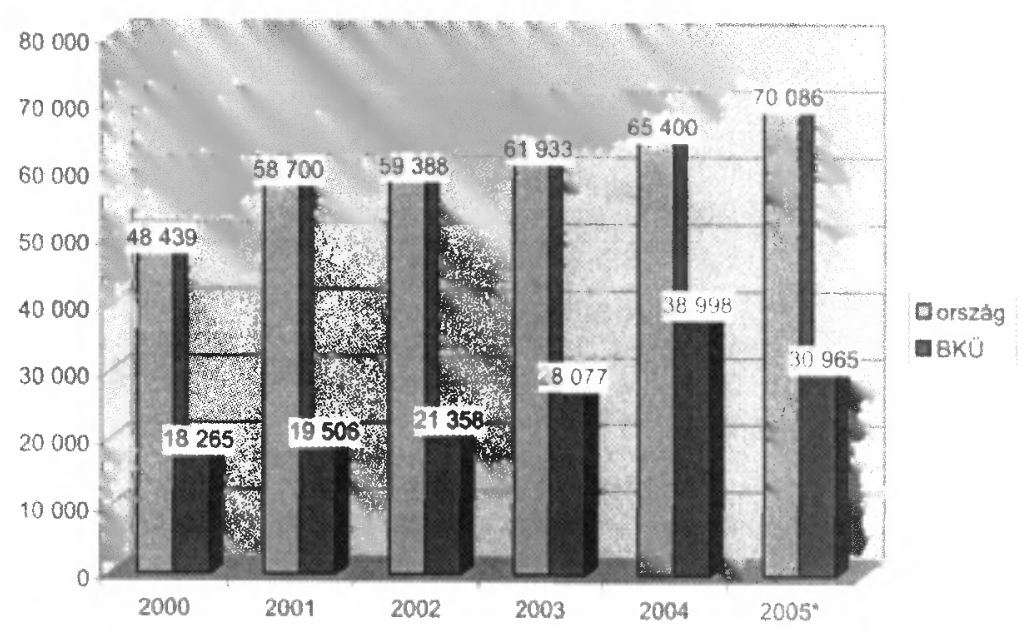

Forrás: A Balaton Régió... $(2005,65)$.

- A térség gazdaságának és a népesség foglalkoztatásának sajátos jellemzője, hogy abban az átlagosnál nagyobb szerepe van a kis- és középvállalkozóknak, amit az is mutat, hogy a térségben a vállalkozások száma (103 db/1000 lakos) Budapest után a legmagasabb, és a vidéki átlagot másfélszeresen $(62 \mathrm{db} / 1000$ lakos) meghaladja. Ez a helyzet már a szocialista időszakban kialakult, mert bebizonyosodott, hogy a turizmus idényszerüségéhez a kisvállalkozások tudnak leginkább alkalmazkodni. Gondot jelent azonban ezeknek a vállalkozásoknak a tőkeszegénysége és sok esetben nem kielégítő szakmai felkészültsége, piacismerete. Ezzel magyarázható például, hogy a szálláshelyadással, vendégfogadással foglalkozó idegenforgalmi vállalkozások száma 2000 és 2006 között 4769-röl 1948-ra csökkent (7. ábra).

- Már évszázados, megoldatlan gond a balatoni turizmus idényszerüsége, a turisztikai idény rövidsége és a turisták alacsony költése. Ez nagyrészt összefügg a turisztikai szállás és programkínálat nem kielégítő színvonalával és hiányosságaival (pl. vitorláskikötők, horgásztanyák stb.).

- Az előzőekben említett gondot növeli az, hogy sem a lakosság, sem pedig az idegenforgalmi szolgáltatásokban dolgozók szakmai felkészültsége, nyelvtudása, mentalitása sok tekintetben nem felel meg a nemzetközi turizmus követelményeinek. 


\section{7. ÁBRA}

Az idegenforgalomban és vendéglátásban érdekelt vállalkozások számának alakulása

2000-2006. szeptembere között

(Number of Companies Engaged in Accommodation and Catering Sector,

2000-2006 [September])

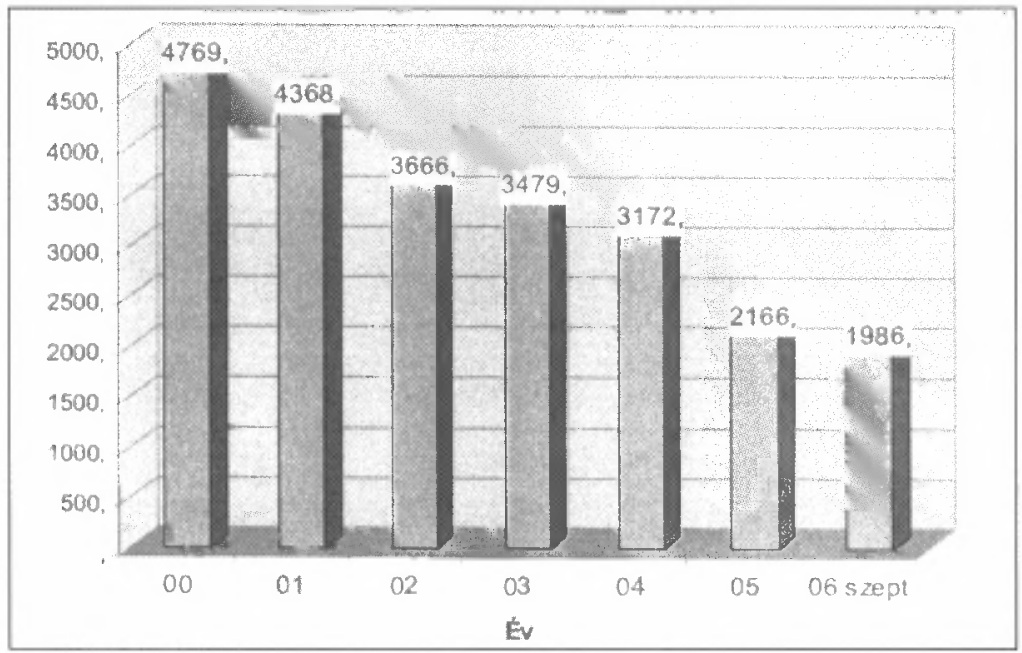

Forrás: Balaton Régió... $(2005,67)$.

- A térség lakosságának szerkezetében kedvezötlen változások jelentkeznek. A népességet az idősebb korúak betelepülése tartja fenn. A munkahelyek idényszerü jellege és a magasan kvalifikált munkahelyek kínálatának hiánya miatt a szakképzett fiatalok elköltöznek, és ez egy kedvezőtlen korstruktúrájú lakosság kialakulását eredményezi, és az időszakos (üdülési idényen kívüli) munkanélküliséget magasan tartja.

- A jövőt tekintve nagy gondot jelent a mezőgazdasági területek szétforgácsolása, jelentős földspekuláció jelenléte. A tőkeszegény, kis területeken megfelelő szakértelem nélkül gazdálkodók nemcsak fejlesztésre, versenyképes termelésre képtelenek, de a környezetkíméló termelés feltételeinek megteremtésére sem (erózió elleni védelem, szakszerú tápanyaggazdálkodás, korszerủ növényvédelem). További gondot jelent, hogy örökléssel a szőlöterületek további felaprózódása várható, ami a termelésben nem érdekelt tulajdonosok esetén a földterület kivonására, telkek létesítésére vonatkozó törekvéseket erôsíti, ami értékes termőhelyeket tehet tönkre.

- A térség megközelítése mind közúti, mind pedig vasúti szállítás esetében Dél-Dunántúl és Észak- és Nyugat-Dunántủl irányából rendkívül nehézkes. A vasúti infrastruktúra a tó körül lényegesen elmarad a 21. században kívánatostól. További gondot okoz az északi part nehéz közúti megközelíthetösége.

- A hulladéklerakók elhúzódó beruházása miatt több térségben megoldatlan a települési hulladékok szakszerủ kezelése, lerakása. 


\section{A fejlesztés szempontjai}

Mivel a térségben végbemenő mindenirányú fejlesztés a Balatonhoz kapcsolódik és a tó minőségének a megörzésével, javításával egyidejúleg kell megtörténnie, nagyon fontos annak tisztázása, hogy minek tekintjük a Balatont. Eddig minden fejlesztés a Balatont szolgájának tekintette. Az idegenforgalom tóra alapozott fejlesztésével profitot lehet termelni, de nem különbözött ettől az önkormányzatok, a szolgáltatók, üdülố vendégek és a helyi lakosság mentalitása sem, akik a Balatonban a haszonszerzés lehetőségét látták, és a tavat olyan tárgyként kezelték, amelynek az ő igényeiket ki kell elégítenie. „Ha kell, akkor még a kormányt is bepereljük, ha a kevés eső miatt alacsony a vízszint, ha pedig a sok eső miatt az magas, akkor pedig azért, mert veszélyezteti az ingatlanainkat". A lényeg az, hogy sem a gazdaság szereplöi, sem az üdülök, sem pedig a helyi lakosság nem úgy tekintett a tóra, mint egy érzékeny, sérülékeny természeti képződményre, amelyet meg kell védeni mindenféle károsodástól, terheléstől. A másik véglet a természetvédelem megközelítése, amely a Balatont és környezetét egy természetes tájnak tekinti, és a gazdaság és a helyi lakosság érdekeit is erősen sértve közpénzen mocsarak létesítésével, a helyi lakosság kitiltásával valami ősi állapot kialakítására törekszik, és még olyan, a tó életét javító munkálatok elvégzését is korlátozza, mint a tó kotrása, a meredek hegyoldalak erdősítése, vagy az avas nád rendszeres eltakarítása.

A Balaton a siófoki zsilip megépítése, partvonalainak kialakítása óta nem tekinthetö természetes, csak egy még nagyfokú önszabályozó rendszerrel rendelkezö természetszerủ tónak, hiszen a vízszint magasságát, a partvonalának jellegét, hosszát, a tóba jutó terhelés mértékét, élóvilágának gazdagságát a környezetében élő ember tevékenysége határozza meg. Ennek a ténynek a nehéz elfogadását tükrözi a vízszint ingadozás példája, amely pedig a tó természetszerúségének egyik jele, és a partvonalak kiépitéséig fontos szerepe volt abban, hogy a tó a felesleges terhelésétól meg tudott szabadulni (8. ábra). Ahelyett, hogy ennek a fontosságát elismernénk, már 100 éve az állandó vízszint tartása érdekében kutatják a vízpótlás lehetőségeit a Dunából, Drávából, Murából, Marcalból, holott arra 100 évből 96 évben a vízfelesleg miatt nincs szükség.

A Balaton régió egy természetszerủ állapotban lévő tóra épüló üdülőtáj, ahol a szabályozás jelentős részének átvételével rendkívüli mértékben megnött az ember felelössége. Elsődleges feladat a szennyezés csökkentése érdekében a Balatonba jutó vizek minőségének a megőrzése (települések csatornázása, szennyvizek tisztítása, településekről elfolyó csapadékvizek tisztítása, a hulladékok szakszerủ kezelése); a Balaton hordalék termelödésének a csökkentése (a befutó vizek ülepítése Kis-Balaton I-II., víztározók, torkolati szűrőmezők); a szőlőkben a teraszok kialakításával, a szőlők és gyümölcsösök sorainak gyepesítésével, a meredek területek pl. Zala völgye, Balaton-felvidék - erdősítésével az erózió mérséklése; a parttól távol az átmenő forgalmat lebonyolító utak építésével, a Balaton felvidéki gyepek erdősítésével a porterhelés csökkentése és a balatoni avas nád rendszeres eltávolítá- 
sával, a tóba került iszap kotrásával a tó belső tápanyagterhelésének a mérséklése. A térségbe érkező turistákat nem az időjárás miatt természetszerüleg kialakuló alacsony vagy magas víz vonza vagy taszítja, hanem az iszapos strand, a rothadó náddal, haltetemekkel szennyezett víz riasztó hatású a számukra.

\section{8. ÁBRA}

Természetes vizkészlet-változás alakulása a Balatonon 1921-2004 (Change of the Total Stock of Water in the Lake Balaton, 1921-2004)

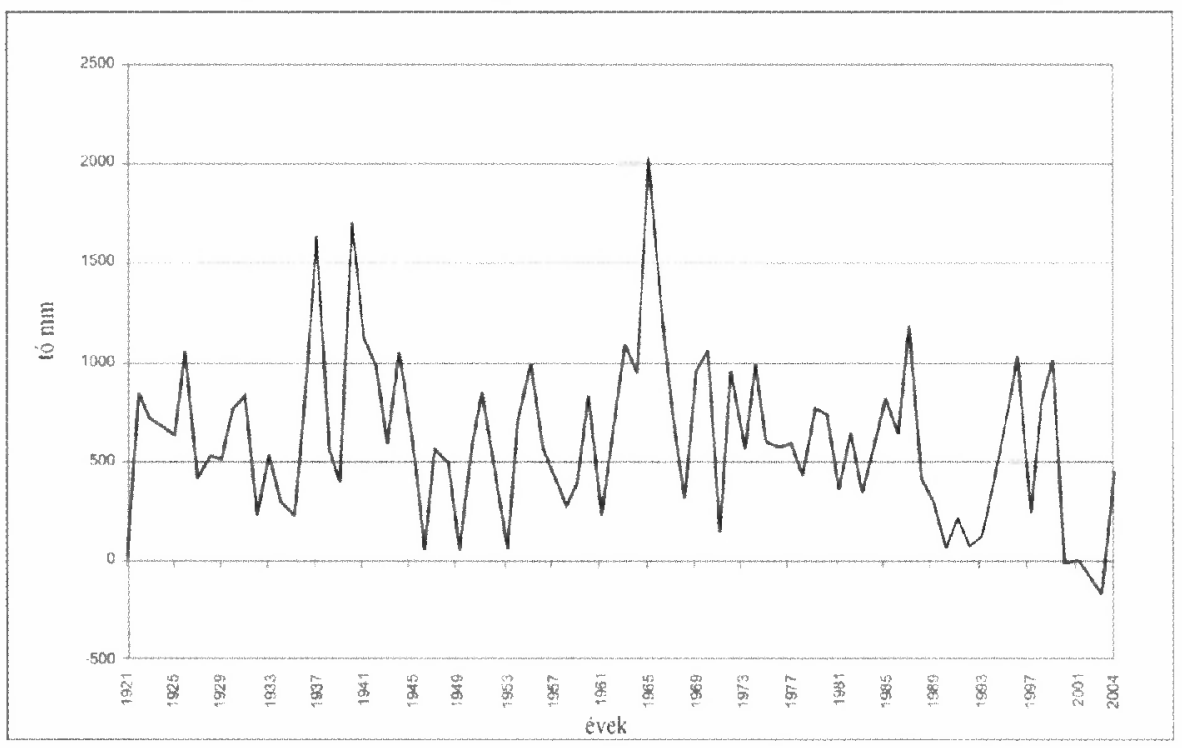

Forrás: Katona-Örsi (2007, 7. ábra).

A térség gazdasági alapját jelentö idegenforgalom alapvető problémája az idegenforgalom szezonális jellege, a turisták rövid tartózkodási ideje és fajlagosan alacsony költése. Erre megoldásként mindig a minőségi turizmus fejlesztését javasolják, a „minőség" fogalmának pontos definiálása nélkül. Ha ezen kizárólag a nagy anyagi erővel rendelkező rétegeket értik, akkor az ilyen irányú javaslatok elfogadhatatlanok, mert azok száma a tó nyújtotta potenciál kihasználására sohasem lesz elegendő. A Balaton korábban is és ma is elsösorban a magyar lakosság pihenő és fürdöhelye volt és lesz, és annak igényeit kell kielégítenie. A turizmus minőségi fejlesztése - a magasabb fokozatú szálláshelyek számának növelése mellett - azt jelentheti, hogy a vendégfogadás feltételeinek és az ahhoz kapcsolódó szolgáltatásoknak a színvonala a kempingektöl kezdve az öt csillagos szállodáig meg kell, hogy feleljen a nemzetközi követelményeknek. Így a térségben egyaránt szerepe van az ifjúsági, a fürdésre alapozott hedonista, a gyógy- és családi turizmusnak és az ún. elit igények kielégítésének is, csak ezek tudatos, egymást nem zavaró módon történő elkülönült fejlesztésére kell törekedni. Ez azért is fontos, mert a térségben élő, turizmushoz kötődő vállalkozások döntő többségét a fagylaltostól, büféstől és szobakiadótól kezdve az éttermi szolgáltatásokig nem a magas jövedelmü, hanem a kispénzes turisták költései tartják életben. 
Az elmúlt évtizedekben a vállalkozások nehézségeit éppen a szerényebb igényű turisták számának radikális csökkenése okozta. Ezzel egyidejúleg igényesen bỏvíthető a turisztikai kínálat (horgászat-horgásztanyák, vitorlázás-vitorláskikötök, lovagoltatáslovásztanyák, golfozás-golfpályák, szervezett bortúrák, kerékpáros turizmus). Ezt egészítheti ki a háttértelepülésekre telepíthetö terepmotorozás és kerékpározás, hölégballonozás, vitorlásrepülés stb. A fejlesztés fontos részét képezi - föleg a déli parton a melegvizes, illetve hévizes fürdőhelyek (pl. Csisztapuszta, Nagyberény, Balatonszárszó) koncentrált fejlesztése. Ezek együttesen képesek az üdülési szezon meghoszszabbítására, az időjárás érzékenységének a csökkentésére és a háttértelepüléseknek az idegenforgalomba való nagyobb mértékủ bekapcsolására, és ezzel a part menti és háttértelepülések közötti fejlettségbeli és jövedelem különbségek mérséklésére. Ennek megvalósítására azonban a települések nagyobb mértékủ együttműködésére és a jelenlegi versenyhelyzettel szemben, a települések közötti partneri viszonyok kialakítására lenne szükség. Ez az együttmüködés lehetövé tenné, hogy eddig a településeken végrehajtott kisstílü, párhuzamos fejlesztésekkel szemben több település érdekeit szolgáló oktatási, egészségügyi, kulturális és üdültetési kapcsolatok alakuljanak ki, amelyek egyszerre szolgálják a helyi lakosság és az üdülök érdekeit is.

A turizmus szempontjából kiemelkedö szerepe van a térség gyors megközelíthetőségének is. Ez a déli part esetében Budapest irányából mind közúton, mind pedig vasúton (föleg, ha ez utóbbi végre eléri a 21 . századi színvonalat) jól megoldható, de az északi part megközelítése már sokkal nehézkesebb, ahhoz a veszprémi foútvonal, valamint a Veszprém-Tapolca közötti közút fejlesztésére lenne szükség. Az északi part vasúti közlekedése is elmaradott (rossz pálya, diesel vontatás, nehézkes kapcsolat a déli vonallal). Ma ennél is nagyobb gondot okoz a Balaton észak (Győr), északnyugat (Sopron), dél (Pécs, Kaposvár) irányú megközelíthetősége, ahonnan a térségbe a legtöbb turista érkezik, és a nyugati turisták megközelítési útvonalát is jelenti. A déli parton külön gondot okoz, hogy a települések közötti összekötő utak hiányában a települések közötti forgalom a part menti utakon bonyolódik le. Minden irányból, a jelentéktelen távolságok ellenére mind a közúti, mind pedig a vasúti megközelítés nehézkes, indokolatlanul sok időt vesz igénybe. $\mathrm{E}$ téren határozott javulás a külföldi turisták számára előnyt nyưjtó légi közlekedés terén következett be a Balaton nyugati részén a sármelléki repülőtér üzembe helyezésével, amit a szentkirályszabadjai (északi part), illetve a siófoki (déli part) repülőtér fejlesztése egészít ki, várhatóan jelentős mértékủ konkurenciát is teremtve egymásnak.

Az idegenforgalom és az ahhoz kapcsolódó szolgáltatások (pénzügyi, egészségügyi, sport stb.) komplex fejlesztése növelheti a térség vonzerejét és teremthet olyan munkahelyeket, amelyek a szakképzett és magasan kvalifikált fiatalok számára is vonzeröt jelentenek, ami által mérséklődhet a térségböl történő elvándorlás. 


\section{A területi irányitás korszerüsitése}

A Balaton régió fejlesztésében visszatérö gondot okoz az elegendő tőkének és egy átfogó fejlesztési szemlélet érvényesülésének a hiánya. Ezen a pályázati rendszer sem segitett, mert az egyes önkormányzatok anyagi lehetőségei erösen eltérőek, és így számottevỏ pályázati pénzekhez csak néhány fejlettebb település jutott. További gondot jelent, hogy a pályázatok is csak egy-egy település gondjainak megoldását segítik, kevésbé a térség egészének összehangolt fejlesztését. Ezért lenne fontos, hogy a Balatoni Fejlesztési Tanács jelentősebb fejlesztési forrásokkal is rendelkezzen, amellyel az általa elkészített fejlesztési tervek megvalósítását is elö tudná segíteni. Meg kell jegyezni, hogy a térségre vonatkozó fejlesztési tervek is sokszor irreálisak, helyi érdekek által meghatározottak (lásd egyidejüleg 3 repülötér fejlesztése, vagy a nagyberényi gyógyvíz Siófokra szállítása, egyidejüleg 5-6 gyógyvizes fürdőhely fejlesztésre kijelölése stb.), miközben nincsenek megoldva olyan alapvetö feladatok, mint pl. a balatoni kerékpárút, a hulladékkezelés, a színvonalas horgászhelyek, vitorláskikötők létesítése, a vasútvonal restaurációja, a történelmi, kultúrtörténeti értékekkel rendelkező fenékpusztai térség rendezése, restaurációja stb.

A part menti települések évszázados törekvései ellenére - amiben a turizmushoz kapcsolódni nem tudó háttértelepülések már kevésbé érdekeltek - a közigazgatás kialakult rendszerében egy önálló Balaton megye vagy fejlesztési régió kialakítására már nincs reális lehetőség. Az adott térségben egyszerre van jelen a fejlesztési források megszerzésében a közös érdek és a part menti és háttértelepülések eltérö fejlettségéből adódó feszültség, ami a térség valamilyen szintủ önállósodása esetén még élesebben jelentkezne. Másrészt a térség mérete, lakosság száma kicsi, gazdasági alapjai - amint azt az elmúlt évtizedek is mutatják - nem elég szilárdak, és a térségnek nincs egy olyan meghatározó jellegủ központja, amely a terület egészének fejlődését alapvető módon befolyásolni tudná. Az elözőeket igazolja, hogy a régió 164 települése közül jelenleg csak 76 település vesz részt a Balatoni Szövetség munkájában, és az önkormányzatoknak csak $71 \%$-a volt tagja egy vagy több területfejlesztési társulásnak.

A turizmus fejlesztésével kapcsolatos közös érdek a part menti, üdülésben érdekelt települések között már a 19. század óta létezik és ezért fürdő egyesületeket, települési szövetségeket hoztak létre (6. táblázat). Ez kezdetben egyáltalán nem volt összhangban a régiót alkotó megyék érdekeivel, és bár ez az érdekellentét enyhült, de ma is létezik. Mind a megyéken, mind a régión belül nehéz kezelni azt a helyzetet, hogy egyes térségek nemzetközi szintre fejlődnek, míg más térségekben az alapvetô infrastrukturális feltételek is hiányoznak. Ezen a helyzeten a térség települései közötti olyan korrekt partneri kapcsolatok kialakítása javíthatna, amely a háttértelepüléseknek a fejlesztésbe történő nagyobb mértékü bekapcsolódásával járna. 
Buday-Sántha Attila : Balaton régió

Tér és Társadalom 22. évf. 2008/4. 43-62. p.

\begin{tabular}{|c|c|}
\hline \multicolumn{2}{|r|}{$\begin{array}{c}\text { 6. TÁBLÁZAT } \\
\text { A regionális irányitás szervezetei } \\
\text { (Organisation of Regional Administration) }\end{array}$} \\
\hline $\begin{array}{l}\text { Megalakulás } \\
\text { ideje }\end{array}$ & Szervezet \\
\hline 1882 & Balaton Egyesület \\
\hline 1898 & Balatoni Múzeum Egyesület - Keszthely \\
\hline 1904 & Balatoni Szövetség \\
\hline 1931 & Magyar Királyi Balatoni Intéző Bizottság - Budapest \\
\hline 1974 & Balatoni Intéző Bizottság - Balatonfüred \\
\hline 1979 & A Balaton Kiemelt Üdülökörzetének kijelölése \\
\hline 1989 & Balatoni Szövetség \\
\hline 1990 & Balatoni Gazdasági Kamara - Balatonfüred \\
\hline 1993 & Balatoni Regionális Tanács \\
\hline 1994 & Balatoni Gazdasági Kör (Kamara jogutódja) \\
\hline 1996 & Államtitkár a balatoni ügyek koordinálására \\
\hline 1996 & Balaton Kiemelt Üdülőkörzet - Fejlesztési régió \\
\hline 1996 & Balatoni Turisztikai Marketing Kht. \\
\hline 1997 & Balaton Fejlesztési Tanács \\
\hline 1998 & Balatoni Regionális Marketing Iroda \\
\hline 2000 & Balatoni Integrációs Fejlesztési Ügynökség - Siófok \\
\hline 2000 & $\begin{array}{c}\text { Turisztikai Rt. Balatoni Regionális Projekt Iroda - } \\
\text { Balatonfüred }\end{array}$ \\
\hline 2001 & A Balatoni Civil Szervezetek Szövetsége \\
\hline 2002 & Balatoni Főépitészi Hivatal - Keszthely \\
\hline 2003 & Balatoni Borrégió \\
\hline
\end{tabular}

Forrás: Saját szerkesztés.

\section{Irodalom}

A Balaton Régió fejlesztési stratégiája 2007-2013. (2005) Balatoni Fejlesztési Tanács. Vitál Pro Kft. http://www.balatonregion.hu/ufiles/dok/338/1/1/BFT_Strat 051212.doc

A Balaton üdülókörzet idegenforgalma 2000-2005. (2006) KSH Veszprémi Igazgatóság, Veszprém. http://portal.ksh.hu/pls/portal/docs/PAGE/VESZPREM/KIADVANYOK/ELEMZESEK/2006EV/BAL ATON2005.PDF

Bendefy L.-V. Nagy I. (1969) A Balaton évszázados partvonal változásai. Müszaki Könyvkiadó, Budapest.

Buday-Sántha A. (2007) A Balaton-régió fejlesztése. - Development Issues of the Balaton Region. Saldo Kiadó, Budapest.

Dombi G.--Egerszegi Z.-- Oláh M.-- Retz T. (2007) A Balaton Kiemelt Üdülökörzet hosszú távú területfejlesztési koncepciója (2007-2020). Helyzetelemzés. Balatoni Integrációs és Fejlesztési Ügynökség Kht., Siófok.

Hablicsek L. (2003) A Balaton Régió demográfiai helyzete és népesség-elöreszámitása 1990-2041.

Kézirat. Budapest.

Illés I. (szerk.) (1981) Tavunk a Balaton. Natura Kiadó, Budapest.

Katona O.-Örsi K. (2006) Jelentés a Balaton vízgyüjtöjén 2004. évben végzett vizgazdálkodási, környezetvédelmi tevékenységröl. Közép-dunántúli Környezetvédelmi és Vízügyi Igazgatóság, Közẻpdunántúli Környezetvédelmi, Természetvédelmi és Vỉzügyi Felügyelőség, Székesfehérvár.

KSH Statisztikai Évkönyv. (1980) Központi Statisztikai Hivatal, Budapest.

KSH Idegenforgalmi Évkönyv. (1986) Központi Statisztikai Hivatal, Budapest.

KSH Statisztikai Zsebkönyv (1999) Központi Statisztikai Hivatal, Budapest. 
KSH Statisztikai Zsebkönyv (2005) Központi Statisztikai Hivatal, Budapest.

Löcsei H.-Németh T. (2006) A Balaton Régió gazdasági ereje. Comitatus. 7-8. 7-22. o.

Lukács K. (1931) A Balaton. Magyar Szemle Társaság, Budapest.

Oláh M. (2006) (Ki)útkeresó Balaton régió. - Comitatus. 7-8. 23-33. o.

Oláh M. (2007) A Balaton Kiemelt Üdülökörzet Magyarországon belüli gazdasági pozíciói és részesedé-

se a fejlesztési forrásokból. Balatoni Integrációs és Fejlesztési Ügynökség Kht. Társadalomtudományi

Kutatócsoport, Balatonfüred.

\section{BALATON REGION}

\section{ATTILA BUDAY-SÁNTHA}

The author of this paper, on the basis of his decadelong researches, wants to find answers for the natural, social and economical problems related to Lake Balaton. The detailed and complex analysis based on the evaluation of different sectorial effects and regional aspects contribute to a better recognition and possible changes of the status and development of the Balaton Region. Hence, this work could be a useful and informative literature not only for experts, but also for all those people who are worried about the fortune of Lake Balaton. 